\title{
Paralytic ileus in the patient with tuberculosis of spine
}

\section{Viskasari P. Kalanjati, Rury T. Oktariza, Yahya Yahya \& Abdulloh Machin}

To cite this article: Viskasari P. Kalanjati, Rury T. Oktariza, Yahya Yahya \& Abdulloh Machin (2019): Paralytic ileus in the patient with tuberculosis of spine, British Journal of Neurosurgery, DOI: 10.1080/02688697.2019.1639621

To link to this article: https://doi.org/10.1080/02688697.2019.1639621

曲 Published online: 15 Jul 2019.

Submit your article to this journal $\pi$

Џll Article views: 19

Q View related articles ¿

View Crossmark data $[\pi$ 


\title{
Paralytic ileus in the patient with tuberculosis of spine
}

\author{
Viskasari P. Kalanjati* (D), Rury T. Oktariza*, Yahya Yahya and Abdulloh Machin \\ Faculty of Medicine, Universitas Airlangga-Dr. Soetomo General Hospital, Surabaya, Indonesia
}

\begin{abstract}
Background: We reported a patient with spinal tuberculosis and paralytic ileus. A 56-year-old Javanese male presented with lower limb paralysis and bowel obstruction 2 weeks prior to admission. He was found to have hypoalbuminemia and hypesthesia from the T7/T9 levels and below. Other than increased alanine aminotransferase, hematology and blood chemical tests were normal. MRI and plain abdominal radiographs confirmed the diagnosis of spinal tuberculosis at the T5/6 level and paralytic ileus. Tubercles in the lymphoid tissue of the intestinal submucosa were not seen.

Conclusion: Paralytic ileus may occur in spinal TB.
\end{abstract}

\section{ARTICLE HISTORY}

Received 15 February 2019

Revised 10 June 2019

Accepted 1 July 2019

\section{KEYWORDS}

Pott's disease; paraplegia; intestinal obstruction; inflammation

\section{Introduction}

Dorsal spinal TB is typically associated with neurological complications due to the narrow canal and thoracic kyphosis. ${ }^{1,2}$ Destruction of the intervertebral disk space and vertebral bodies often leads to anterior wedging, kyphosis and gibbus formation. ${ }^{3,4}$ Paraplegia and autonomic nervous system impairment may occur. ${ }^{5,6}$ Here we report a case of spinal tuberculosis accompanied by paralytic ileus and hypoalbuminemia, which were improved gradually after initial treatment.

\section{Case report}

A 56-year-old Javanese male was admitted complaining of weakness of both legs for 2 weeks. He complained of fatigue decreased sensitivity from approximately below the rib cage. He had difficulties with micturition and defecation and mild dull abdominal pain for 9 days. He denied any fever or chronic cough history and was previously well. There were no affected family or neighbours. Vital signs were normal. The abdomen was distended and tympanic. His body mass index was 24.2. Neurological examination revealed paraplegia and hypesthesia from the T7/T9 levels and below. Reflexes were within normal limits.

Hematological and blood chemical examinations other than high ALT and low albumin levels, were within normal limits (ALT $131 \mathrm{U} / \mathrm{L}$, albumin $2.88 \mathrm{~g} / \mathrm{dL}$ ). A paralytic ileus appearance was seen on abdominal $\mathrm{x}$-rays (Figure 1). A Chest $\mathrm{x}$-ray was clear. Spinal MRI showed destructions of the right T5 and both T6 pedicles. There was a paravertebral abcess at $\mathrm{T} 5 / 6$ compressing the spinal cord and forming a curtain sign appearance causing edema at these levels. Abdominal MRI did not show evidence of TB of the gastrointestinal tract or lymphadenopathy (Figure 2).

An NG tube was inserted. The patient was treated for hypoalbuminemia and ileus with intravenous aminofusin and 5\% dextrose in water solutions, ranitidine and vitamins B1, B6 and B12. Anti TB chemotherapy was commenced $500 \mathrm{mg}$ of isoniazid,

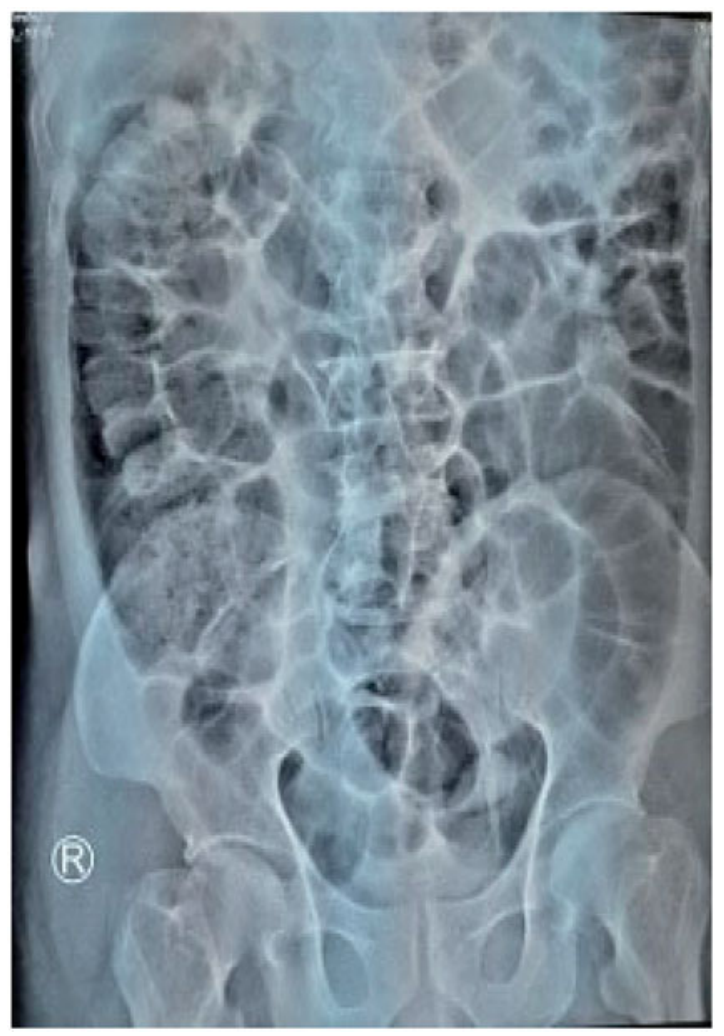

Figure 1. A plain abdominal $x$-ray of the patient showed coiled spring and bowel dilatation mixed with prominent fecal material with distribution until pelvic cavity.

$450 \mathrm{mg}$ of rifampicin, $1000 \mathrm{mg}$ of ethambutol, $1500 \mathrm{mg}$ pyrazinamide daily. Within 9 days, abdominal fullness improved and general condition improved. Further treatment and investigation were halted due to the patient's wishes. 


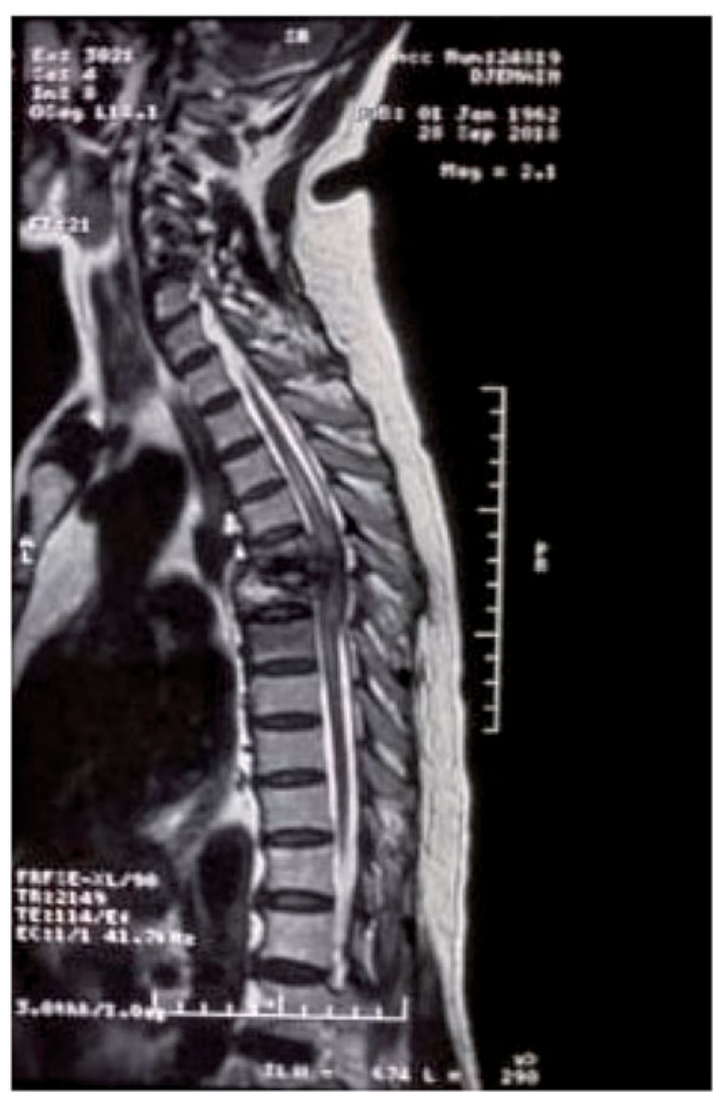

Figure 2. A sagittal view of cervicothoracal MRI with contrast of the patient showed destruction of the fifth and sixth thoracic vertebral bodies and a compression of the spinal cord by an abcess at the concomitant levels.

\section{Discussion}

Our patient suffered from spinal TB was suspected of having abdominal TB as well. We found no electrolyte disturbances that often accompany paralytic ileus. Several medications have been associated with paralytic ileus, including anticholinergics, opiates, calcium channel blockers, clonidine, and psychotropic but our patient was taking no such medications. ${ }^{7,8}$

The abdominal imaging did not show the cause of the ileus. It can be caused by bowel obstruction from TB but we found no evidence of that.

Autonomic nervous system impairment due to the spondylosis tuberculosis could cause a sympathetic and parasympathetic outflow disturbance to the gastrointestinal tract; this would disrupt the peristalsis and cause adynamic ileus. 9,10

Instead of mechanical obstruction, pseudo-obstruction due to neuropathy was the likely mechanism in this case. Inflammation affecting the lateral horn of the spinal cord may cause overactivity of the sympathetics. ${ }^{9-11}$ The autonomic imbalance lead to impaired peristalsis. ${ }^{11-13}$ In addition; the enteric nervous system may also be compromised, thus contributing to the pathophysiology. ${ }^{12,13}$

Adynamic ileus has been reported previously in spinal cord injury due to causes other than tuberculosis i.e. thoracolumbar compression fractures of T8, T12 and $\mathrm{L} 4{ }^{14}$ post-lumbar spinal surgery due to the severe lumbar spinal stenosis of L1-L2 to L4-L5, an unstable degenerative spondylolisthesis at L4-L5 and a ruptured L4-L5 disc; ${ }^{15}$ and herpes zoster infection at L4 level. ${ }^{16}$ In these patients, specific causes of bowel mechanical obstruction were not found. The signs and symptoms of nausea, vomiting, abdominal discomfort, constipation and/or diarrhea with bowel dilatation showed in the abdominal x-rays were reported. ${ }^{14-16}$

\section{Conclusion}

Paralytic ileus in a patient with spinal tuberculosis could be due to the mechanical or neurological complications.

\section{Disclosure statement}

No potential conflict of interest was reported by the authors.

\section{ORCID}

Viskasari P. Kalanjati (D) http://orcid.org/0000-0002-7005-0025

\section{References}

1. Garg RK, Somvanshi DS. Spinal tuberculosis: a review. J Spinal Cord Med 2011;34:440-54.

2. Ha KY, Kim YH. Late onset of progressive neurological deficits in severe angular kyphosis related to tuberculosis spondylitis. Eur Spine J 2016;25:1039-46.

3. Jain AK, Dhammi IK. Tuberculosis of the spine: a review. Clin Orthop Relat Res 2007;460:39-49.

4. Jain AK, Kumar J. Tuberculosis of spine: neurological deficit. Eur Spine J 2013;22:624-33.

5. Debi U, Ravisankar V, Prasad KK, Sinha SK, Sharma AK. Abdominal tuberculosis of the gastrointestinal tract: revisited. WJG 2014;20: 14831-40.

6. Chalya PL, Mchembe MD, Mshana SE, Rambau P, Jaka H, Mabula JB. Tuberculous bowel obstruction at a university teaching hospital in Northwestern Tanzania: a surgical experience with 118 cases. World J Emerg Surg 2013;8:12.

7. Wells CI, O'Grady G, Bissett IP. Acute colonic pseudo-obstruction: a systematic review of aetiology and mechanisms. WJG 2017;23:5634-44.

8. Carreiro FT, Coelho SC, Horta AB, Sa J. Adynamic ileus and diarrhoea: a rare adverse effect of antidepressants. BMJ Case Rep. 2015; 2015:bcr2014208095.

9. Wrenn SM, Parsons CS, Yang M, Malhotra AK. Acute large bowel pseudo-obstruction due to atrophic visceral myopathy: a case report. Int J Surg Case Rep 2017;33:79-83.

10. Awad RA. Neurogenic bowel dysfunction in patients with spinal cord injury, myelomeningocele, multiple sclerosis and Parkinson's disease. WJG 2011;17:5035-48.

11. Brock C, Brock B, Pedersen AG, Drewes AM, Jessen N, Farmer A. Assessment of the cardiovascular and gastrointestinal autonomic complications of diabetes. WJD 2016;7:321-32.

12. Turner MP, Arndtz S, MacFaul G. Acute colonic pseudo-obstruction associated with abdominal paracentesis. BMJ Case Rep 2017;2017: bcr2016216077.

13. Watson N. Late ileus in paraplegia. Paraplegia 1981;19:13-6.

14. Treadwell EL, Cunningham PR, Kowalski HM, Weaver MD. Thoracolumbar compression fractures presenting with an acute ileus. J Natl Med Assoc 1990;82:669-72.

15. Feldman RA, Karl RC. Diagnosis and treatment of Ogilvie's syndrome after lumbar spinal surgery. Report of three cases. J Neurosurg 1992;76: 1012-6.

16. Chung JY, Park JS, Kim YS. A rare cause of acute colonic pseudoobstruction: Ogilvie's syndrome caused by herpes zoster. $J$ Neurogastroenterol Motil. 2017;23:616-7. 